\title{
УДК552.113
}

\section{ПЕТРОЛОГИЧЕСКИЕ АСПЕКТЫ СОВРЕМЕННОГО ОСТРОВОДУЖНОГО ВУЛКАНИЗМА НА ПРИМЕРЕ ЛАВ ВУЛКАНА БАТУР (О. БАЛИ, ИНДОНЕЗИЯ)}

\author{
Якич Тамара Юрьевна1, \\ cherkasovatu@tpu.ru
}

\author{
Савинова Олеся Вячеславовна ${ }^{1}$, \\ logvinenkoov@tpu.ru
} Рудмин Максим Андреевич1,
rudminma@tpu.ru
1 Национальный исследовательский Томский политехнический университет, Россия, 634050, г. Томск, пр. Ленина, 30.

\begin{abstract}
Актуальность изучения современного вулканизма заключается в понимании сложных процессов диффреренциации, ассимиляиии и смешения магм, зафиксированных в минералого-петрогеохимических и текстурно-структурных особенностях строения современных вулканитов. С другой стороны, с базитовым вулканизмом повышенной щелочности современных островодужных систем зачастую связано экономически значимое оруденение цветных и благородных металлов. Целью настоящей работы является изучение и интерпретация минералогических и петрохимических особенностей лав действующего вулкана Батур (о. Бали, Индонезия). Объектами исследования являются вулканиты, отобранные из лавовых потоков 1964 г. извержения действующего вулкана Батур. Породы современного островодужного магматизма и встречающиеся в них минералы изучены методами оптической и электронной микроскопии с применение энергодисперсионной спектроскопии. Химический состав основных петрогенных компонентов получен с помощью силикатного анализа, микроэлементный состав - с помощью масс-спектрометрии с индуктивно-связанной плазмой. В результате проведенных исследований было установлено, что все образцы изученных вулканитов имеют порфировую структуру и содержат вкрапленники плагиоклаза (17...23 об. \%), оливина (3 об. \%) и пироксена (2 об. \%), расположенных в мелкозернистой массе мезостазиса, содержащего плагиоклазы, титаномагнетит, пироксен и вулканическое стекло. Для порфировых вкрапленников плагиоклаза характерна «ячеистая» структура, которая проявлена в виде ориентированных расплавных включений ( 0,05 мм), содержащих первичный силикатный и сульфидный расплавы. По петрохимическим показателям породы относятся к высокоглиноземистым базальтам $\left(\mathrm{Al}_{2} \mathrm{O}_{3} \geq 18,0\right)$. Сложный характер зональности порфировых вкрапленников плагиоклазов согласуется с быстрым охлаждением исходных расплавов, когда выделяющийся плагиоклаз не может прийти в равновесие с оставщейся еще жидкой магмой, по средневзвешенному составу он относится к лабрадор-битовниту. Оливин сочетает несколько вариантов перераспределения железа в своем составе. Отмечается прямая зональность с накоплением железа в краевых частях зерен, специфичные «структуры распада» с фразой «окси-оливина» и однородные кристалль оливина с магнезиальностью $\mathrm{Mg \#}(\mathrm{Fo})\left[=\mathrm{Mg} /\left(\mathrm{Fe} \mathrm{e}^{2+}+\mathrm{Mg}\right)^{\star} 100 \%\right] \sim 66$. Повышенная железистость оливина и примесь в нем МnО служат свидетельством того, что изучаемые породы являются производными базальтовых растворов с щелочным уклоном. По представлению авторов механизм формирования изучаемой серии андезибазальтов имеет следующий сценарий формирования. В период интенсивного вулканизма 1964 г. извержения вулкана Батур магматическая камера периодически обогащалась высокомагнезиальным (оливиновым) базальтом через определенные промежутки времени. Далее этот расплав поднимался в верхнюю часть камеры с последующим фрракционированием оливина и клинопироксена при кристаллизации плагиоклаза и накоплением его в верхней части магматической камеры. В период поступления новой порции родоначального расплава существующая смесь не успевала прийти в равновесие с поступившей порцией расплава, изливаясь на поверхность и формируя лавы высокоглиноземистого базальта. Включения глобулей ковеллина и халькопирита в расплавных включениях порфировых вкрапленников плагиоклаза свидетельствуют о существовании высокофракционированного сульфидного расплава на более глубинном уровне.
\end{abstract}

\section{Ключевые слова:}

Современный островодужный вулканизм, высокоглиноземистье базальты, плагиоклаз, оливин, расплавные включения, сульфидные глобули.

\section{Введение}

Островная дуга Сунда-Банда является классическим примером процессов активного вулканизма, происходящего в условиях конвергентных границ или зоны субдукции [1-4]. Известно, что излившиеся вулканиты питаются магмами, генерируемыми в мантии, но при этом связь между мантией и изверженными на поверхность породами практически стерта из-за различных процессов кристаллизации, смешения, ассимиляции, происходящих в Земной коре до того момента, как исходная магма достигнет земной поверхности $[5,6]$. Несмотря на то, что изменение состава первичных расплавов значительно затрудняет петрогенетические реконструкции, композиционный состав первичных минералов и, в некоторой степени, текстурно-структурные особенности изверженных пород способны сохранить в себе важную петрогенетическую информацию [7]. Так, по изучению поведения никеля в оливинах из лавового потока последнего (1963-1965 гг.) извержения действующего вулкана Иразу (Коста-Рика) P. Ruprecht и T. Plank [8] установили, что современные андезибазальты зарождаются на границе мантии и земной коры (граница Мохоровича $30 \ldots 35$ км) и, поднимаясь на поверхность, испы- 
тывают различные процессы дифференциации, гибридизации и смешения за очень короткий промежуток времени - от нескольких месяцев до нескольких лет. Эта же гипотеза подтверждается изучением диффузионного перераспределения железа во вкрапленниках оливина не только на примере вулкана Иразу [9], но и в других вулканитах подобных островодужных систем [10, 11].

С другой стороны, островная дуга Сунда-Банда, как и другие вулканические провинции, связанные с зонами субдукции, является областью локализации экономически значимых медно-порфировых и эпитермальных Au-Ag месторождений [12-16]. Известно, что эволюция большинства мантийных и коровых силикатных магм неизбежно приводит к несмесимости силикатного и несиликатного расплавов [17]. Такая несмесимость двух или более жидких и паровых фаз происходит во время непрерывно изменяющихся условий, связанных с декомпрессией магмы, охлаждением, кристаллизацией, гибридизацией и т. д. [17]. Однако формирование сульфидного оруденения в условиях, связанных с зоной субдукции, по-прежнему остается дискуссионным. Одним из возможных объяснений накопления руды в связи с несмесимостью силикатных и сульфидных магм является вклад магматических сульфидов, образовавшихся в результате смешения базальтовых расплавов более ранних вулканических циклов [17]. Несмотря на то, что несмесимость силикатных и сульфидных фаз в магмах чрезвычайно трудно документировать, в основном из-за их переходного характера, небольших количеств и реактивных качеств, обильное количество глобул сульфидного расплава, захваченного высокомагнезиальным оливином, обнаружено в лавах и шлаках 1941 г. извержения вулкана Толбачик на Камчатской дуге [18-20].

В данной работе были изучены лавы 1964 г. извержения действующего вулкана Батур, расположенного на острове Бали, входящего в структуру более высокого порядка - островную дугу Сунда-Банда. Изучены минералогические, текстурно-структурные и петрохимические особенности пород современного островодужного вулканизма в аспекте интерпретации их петрогенезиса.

\section{Геолого-структурная позиция о. Бали}

Остров Бали расположен в восточной части вулканической островной дуги Сунда-Банда (рис. 1) и сформирован в процессе субдукции движущейся на север океанической Индо-Австралийской плиты под Евразийскую [4]. Толщина Евразийской плиты под Суматрой и Явой составляет около 20...30 км [1-3] и около 18 км недалеко от острова Бали. Субдуцированная плита представляет собой океаническую плиту с возрастом от $\sim 80$ до $\sim 130$ млн лет $[21,22]$. Скорость субдукции Индо-Австралийской плиты под Евразийскую составляет 6...7 см в год [23-25]. Вулканизм на острове Бали возник со времен среднего и позднего четвертичного периода [4, 26-28].

Вулкан Батур (1717 м) является действующим вулканом и относится к группе четвертичных вулканов (Батур, Агунг, Братан, Батукару и Сераджа), располагаю- щихся на северо-востоке острова Бали [4]. Кальдера Батур расположена в восточной части острова Бали, с размером около $14 \times 10$ км² $^{2}$ состоящим из трех периодов образования и двух периодов формирования кальдеры, на что указывает появление двух ободов кальдеры. Вулканическая активность в кальдере Батур началась, по крайней мере, 500 тыс. лет назад, с образованием базальтово-андезитового стратовулкана (вулкан Пенулисан) [29]. Извержение лавы из вулкана Батур имеет широкий диапазон по составу от базальтов до риолитов, что указывает на зрелую ее эволюцию и прогрессивное развитие магматической системы, что привело к катастрофическим кальдерообразующим извержениям.

\section{Методы исследования}

Для изучения минералогических и петрохимических особенностей современных лав вулкана Батур было отобрано 6 образцов из лавового покрова извержения 1964 г. вблизи кальдеры вулкана. Из образцов были изготовлены шлифы и двуполированные пластины. Микроструктурный и элементный анализ проводился на оптическом микроскопе Carl Zeiss и на сканирующем электронном микроскопе Tescan Vega 3 SBU (Чехия, TESCAN), оснащенном приставкой для рентгенофлуоресцентного энергодисперсионного анализа (ЭДС) Oxford X-Max 50 с Si/Li кристаллическим детектором. Ускоряющее напряжение для СЭМ съемки и анализа было 20 кВ с интенсивностью тока зонда в пределах 4...11,5 нА. Локальный рентгеноспектральный анализ выполнялся с предварительной калибровкой интенсивности зонда $(11,4 \ldots 11,5$ нА) по кобальтовому стандарту при рабочем (фокусном) расстоянии 15 мм. СЭМ фотографии накапливались для двух основных детекторов: вторичных электронов (SE - secondary electrons) и обратно-рассеянных электронов (BSE - backscattered electrons) в лаборатории отделения геологии (НИ ТПУ, г. Томск).

Для количественного анализа содержаний элементов из образцов изготовлены навески фракцией 0,1 мм. Содержания микроэлементов в образцах получены методом масс-спектрометрии с индуктивно-связанной плазмой (ЦКП «Аналитический центр геохимии природных систем», г. Томск). Предварительно обожжённую при $800{ }^{\circ} \mathrm{C}$ навеску, около 0,1000 г, разлагали с использованием смеси плавиковой и азотной кислоты в герметичных автоклавах в микроволновой печи при $200{ }^{\circ} \mathrm{C}$. После чего путём выпаривания и растворения сухого остатка отгоняли фториды азеотропом соляной кислоты и переводили соли в нитратную форму. После разбавления раствор пробы анализировали с использованием масс-спектрометра с индуктивно-связанной плазмой Agilent 7500сх. Концентрация элементов в растворе пробы определялась по градуировочным графикам на основе градуировочных растворов производства фирмы Agilent. Расчёт концентраций элементов непосредственно в навеске пробы проводился с учётом потерь при прокаливании, разбавления, внутреннего и внешнего стандарта.

Содержания основных оксидов в породе определены силикатным анализом в ОАО «Западно-Сибирский испытательный центр», г. Новокузнецк. 


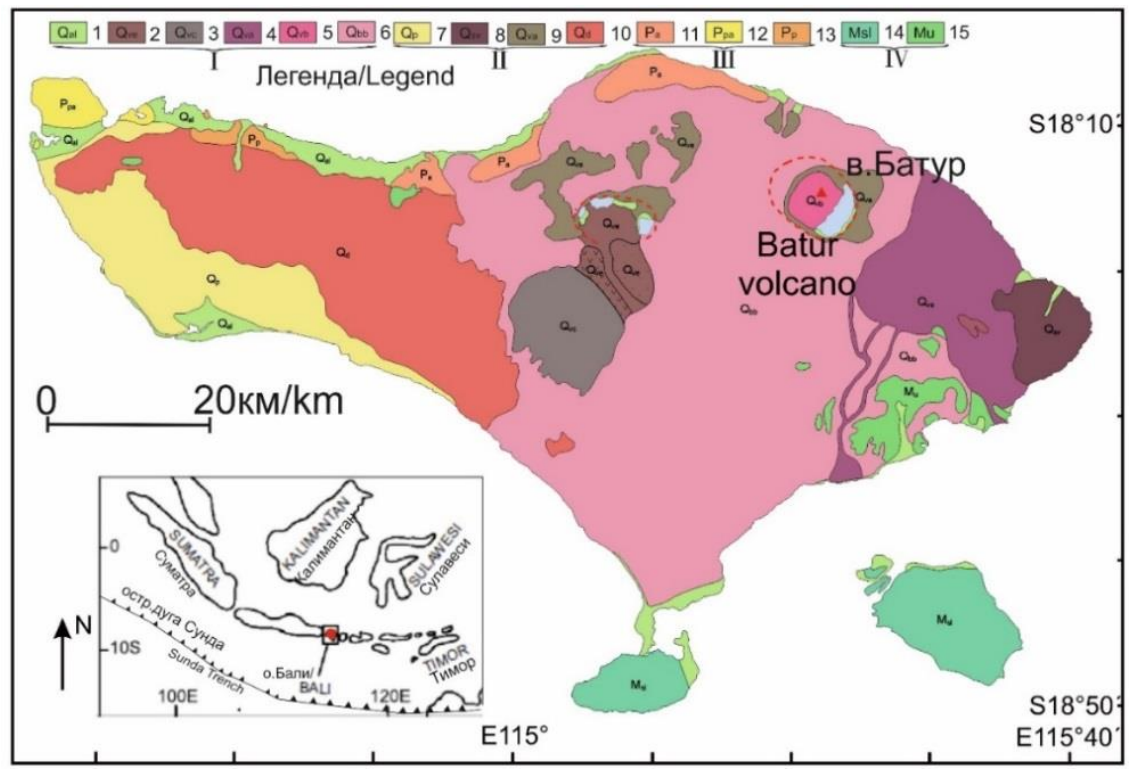

Рис. 1. Схематическая геологическая карта о. Бали с изображением местоположения кальдеры вулкана Батур по данным [29]. Легенда: I - Верхнечетвертичные отложения (Голочен): 1 - аллювиальные отложения; 2 продукты вулканического извержения; 3 - вулканические продукты извержения вулкана Батукао; 4 - вулканичекие продукты извержения вулкана Агунг; 5 - современный вулканогенный материал вулкана Батур; II средне и нижнечетвертичные отложения (Плейсточен и Эоплейстоцен): 6 - туфовые отложения и вулканические селевые потоки вулканов Байан-Братан и Батур; 7 - формация Паласари, состоящая из конгломератов, песчаников, рифовых известняков; 8 - вулканический материал вулкана Серай; 9 - ранние вулканические отложения вулканов Баян-Братан и Батур; III - неогеновые отложения (Плиоцен): 10 - вулканить окрестностей Диембраны, представленные лавовыми потоками, брекчиями, туфами вулканов Келатакан, Мербук, Патас и ассоциирующими с другими породными группами; 11 - формация Асаи, представленная лавами, брекчиями, пемзами и туфами с известковыми трещзинами заполнения; 12 - формация Прапатагунг: известняки, песчаники с карбонатным цементом, мергели; IV - неогеновые отложения (Миоцен): 13 - вулканические отложения вулкана Пулаки: лавы и брекчии; 14 - формация Селатан, представленная преимущественно известняками; 15 - формация Сорга: туфы, мергели, песчаники; 16 - формация Улакан, состоящая из вулканических брекчий, лавовых потоков и туфов с прослоями известкового материала

Fig. 1. Schematic geological map of the Bali Island showing the Batur Caldera location after [29]. Legend: I - Quaternary: 1 - Alluvial deposit; 2 - volcanic products; 3 -volcanic products of Batukao volcano; 4 - volcanic products of Agung volcano; 5 - volcanics of Batur volcano; II - Lower Quaternary: 6 - Bajan-Bratan and Batur tuffs and volcanic mudflows; 7 - Palasari Formation: conglomerates, sandstones, reef limestones; 8 - Seraja volcanics; 9 volcanics of old Bajan-Bratan volcano and old Batur volcano; III - Pliocene: 10 - Djembrana volcanics: lavas, breccias, tuffs of the volcanoes Kelatakan, Merbuk, Patas, and associated rocks; 11 - Asah Formation: lavas, breccias, pumiceous, tuffs with calcareous crack fillin; 12 - Prapatagung Formation: limestones, calcareous sandstones, marls; IV-Miocene: 13 - Pulaki volcanics: lavas and breccias; 14 - Selatan Formation: predominantly limestone; 15 - Sorga Formation: tuffs, marls, sandstones; 16 - Ulakan formation: volcanic breccias, lavas, tuffs with intercalations of calcareous material

\section{Результаты и их обсуждение}

\section{Особенности минерального состава}

Основные породообразующие минералы представлены плагиоклазом, пироксеном и в меньшей степени оливином.

Плагиоклаз - наиболее распространенный минерал порфировых вкрапленников изучаемой андезибазальтовой серии вулканитов. Размер кристаллов различен - от 0,01 мм в виде вкраплеников в мезостазисе и до 1,5 мм в порфировых вкрапленниках. Порфировые вкрапленники плагиоклаза характеризуются наличием сложного двойникования, сочетающего различные виды блоковой зональности и резкие переходы между отдельными слоями. Присутствуют как округлые (оплавленные) очертания внутренних ядерных частей, так и прямая зональность. Сложный характер зональ- ности порфировых вкрапленников плагиоклазов согласуется с быстрым охлаждением исходных расплавов, когда выделяющийся плагиоклаз не может прийти в равновесие с оставшейся еще жидкой магмой. Другим объяснением сложного строения плагиоклазовых вкрапленников с округлыми внутренними зонами могут являться процессы дегазацией магмы при извержении, что связано со вскипанием и повышением температур, приводящих к оплавлению границ кристаллов, которые затем обрастают внешними каймами.

По химическому составу порфировые вкрапленники плагиоклаза соответствует лабрадору-битовниту с широкой вариацией содержания анортитовой молекулы в диапазоне (An 57...80 \%). При этом плагиоклазы, захваченные в расплавных включениях пор- 
фировых вкрапленников плагиоклаза, имеют еще более разнообразный состав, от среднего (An 48...56\%) до основного, соответствующего битовниту с содержанием анортитовой молекулы (An $80 . .85$ \%).

Пироксен представлен главным образом клинопироксеном, который по составу в большинстве случаев отвечает авгиту. Фенокристы пироксена имеют размер зерен $\sim 0,1 \ldots 1,3$ мм. Однако в качестве захваченных включений в титаномагнетите отмечаются и ортопироксены, а также ортопироксены, содержащие ламели клинопироксена.

Оливин характеризуется широкими вариациями своего химического состава. Размерность его зерен колеблется в пределах 0,1..0,6 мм. Максимальное различие в содержании форстеритового минала $(\mathrm{Fo})=\left(\mathrm{Mg} \#=\left[\mathrm{Mg} /\left(\mathrm{Fe}^{2+}+\mathrm{Mg}\right) \times 100 \%\right]\right)$ в пределах одного образца наблюдается в образце базальта № 1084_2, где оливин характеризуется переменным составом с колебанием форстеритовой молекулы от $86 . .46 \%$ и образует специфичные «структуры распада». По всей видимости, подобные структуры представляют собой раннюю стадию окислительного распада оливина в виде фазы «окси-оливина». Эта фаза структурно близка вмещающему оливину и поэтому может образовывать правильно ориентированные пластинки оливиноподобной фазы, обогащенной $\mathrm{Fe}^{3+}$. Такая сверхструктура может возникать при некоторых процессах упорядочения. На более поздней стадии эти пластинки должны разлагаться на пироксен и магнетит. На снимках СЭМ фиксируется тот факт, что в матрице магнезиального оливина с (Fo $78 \ldots 86 \%$ ) (рис. 2) располагаются вростки железистого оливина c (Fo 46...62 \%) (рис. 2). Также наблюдаются и 30нальные зерна оливина с накоплением железа в краевых частях, характерные для трахиандезибазальтового порфирита (обр. 1084_3) (рис. 3).

В количестве от $1 \ldots .7 \%$ в изучаемых вулканитах встречается оксид титана и железа - титаномагнетит. Его размерность различна и варьирует в широких пределах от $0,01 \ldots 1,0$ мм. В единичных случаях отмечается магнетит и ильменит. Из сульфидов отмечены преимущественно сульфиды меди: халькопиpuт и ковеллин, в виде округлых глобулей, захваченных в расплавных включениях плагиоклазовых порфировых вкрапленников (рис. 4).
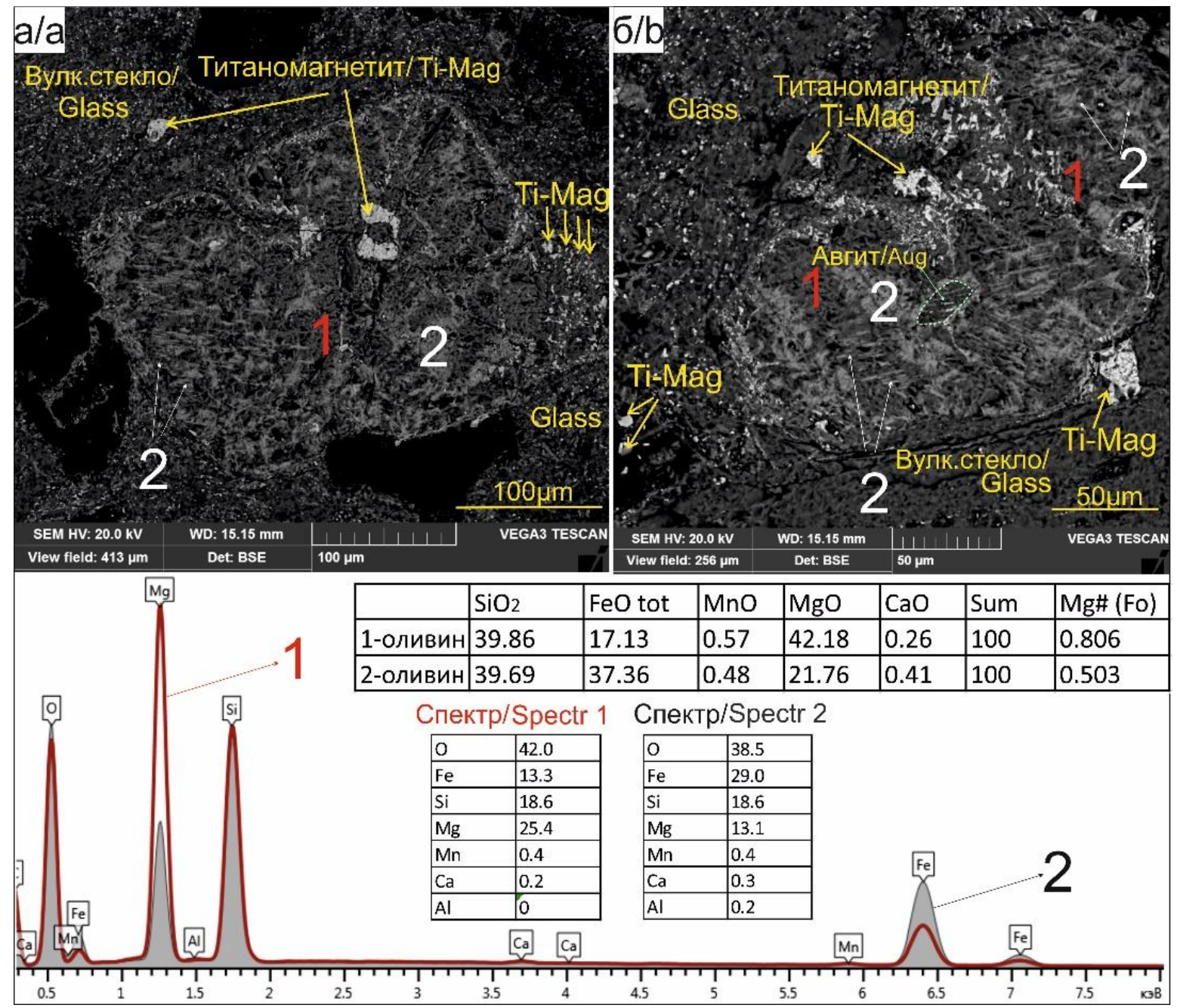

Pис. 2. Зерно оливина с фазой «окси-оливина» в ассоииации с титаномагнетитом (а) и авгитом (б) в базальте (обр. 1084_2)

Fig. 2. Olivine grain with "exsolution» in association with titanomagnetite (a) and augite (b) in basaltic porphyry (sam.1084_2). Abbreviations: Aug - augite, Ti-mag - titanomagnetite 


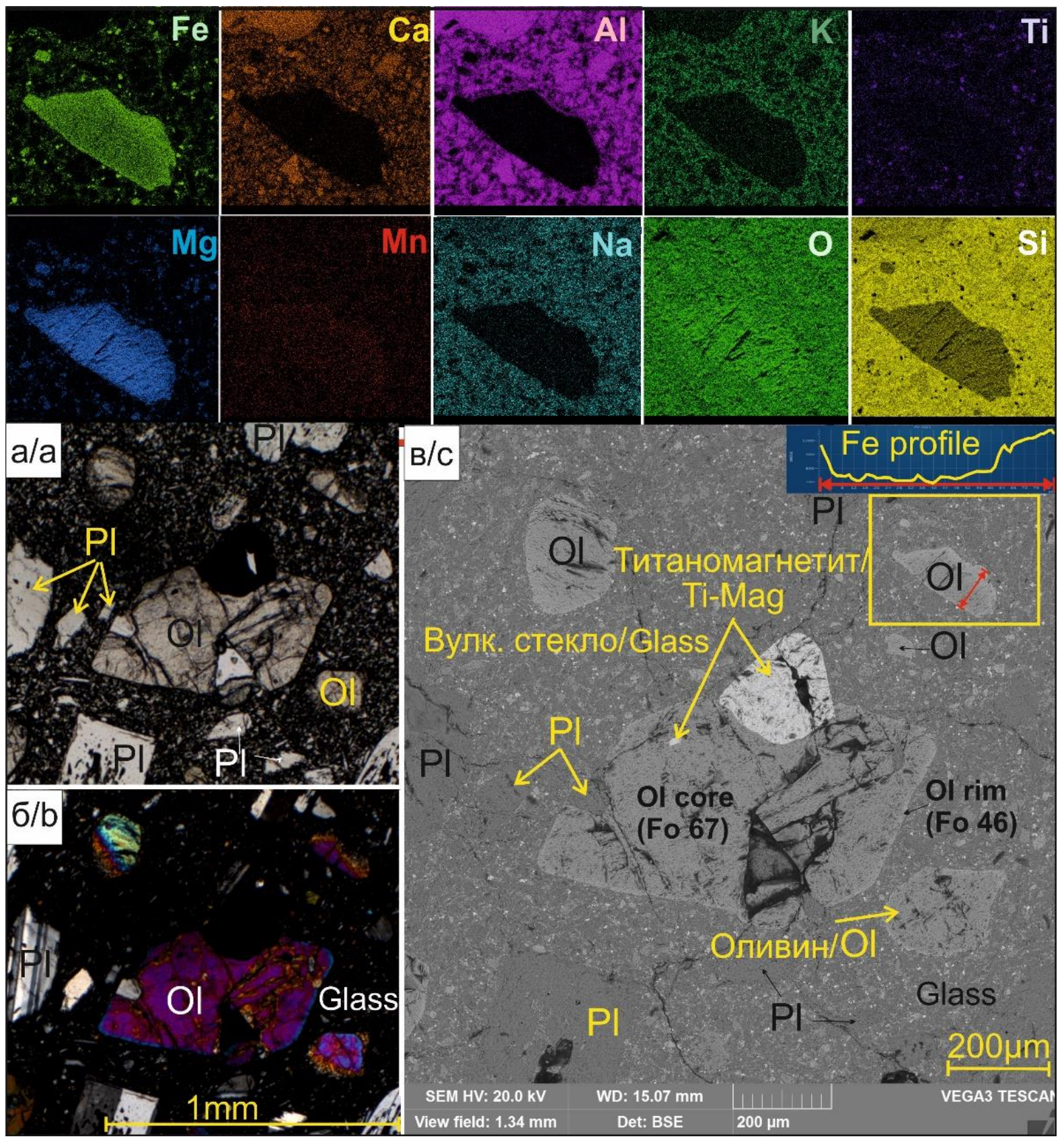

Pис. 3. Элементная карта распределения химических элементов на участке, содержащем зональное зерно оливина; микрофотографии участка, содержащего зональные кристаллы оливина в параллельных (а) и скрещенных (б) николях, а также в обратно-отраженных электронах сканирующего микроскопа (в) в трахиандезибазальте (обр. 1084_3)

Fig. 3. Elemental map illustrating the distribution of elements on the area containing zonal olivine grain. Transmitted-light microphotographs of the area containing zonal olivine grains in plane (a) and cross-polarized (b) light. Backscatter electron images (c) of the same area in the trachyandesibasalt (sam. 1084_3). Abbreviations: Ol - olivine; Pl plagioclase; Ti-mag - titanomagnetite

\section{Петрографическая характеристика}

Основная группа изученных вулканитов представлена базальтами нормального ряда и базальтами с щелочным уклоном.

Трахиандезиобазальт I типа сложен главным образом вкрапленниками плагиоклазов $(80 \ldots 90 \%)$, клинопироксена $(10 \ldots 15 \%)$ и оливина $(5 \ldots 7 \%)$.

Количество порфировых вкрапленников колеблется в пределах $35 . .40$ \% от общего объема породы. В основной массе встречаются как крупные фенокристы (вкрапленники) плагиоклазов (до 1,5 мм), так и мелкие кристаллы (до 0,02 мм), формирующие интерсертальную структуру основной массы порфирита (рис. 5, а, б). По составу порфировые вкрапленники плагиоклаза соответствует лабрадору - битовниту с содержанием анортитовой молекулы (An 67...73\%). Фенокристы пироксена имеют размер зерен $\sim 1 \ldots 1,0$ мм. В подавляющем большинстве случаев они представ- 
лены авгитом. Оливин встречается спорадически и представляет собой высокожелезистую разновидность с (Fo $60 . .67$ \%). Размерность зерен оливина до 0,1 мм, повсеместно по краям он замещается иддигситом ярко буро-оранжевого цвета, что подчеркивает его высокую железистость.
В количестве $1 . .3 \%$ встречается оксид железа с примесью титана - титаномагнетит.

Базальт сложен в свою очередь вкрапленниками плагиоклазов $(80 \ldots 85 \%)$, оливином $(10 \ldots 15 \%)$ и, в менышей степени, клинопироксеном (5...7\%). Количество порфировых вкрапленников от общего объема составляет $40 . .50 \%$.

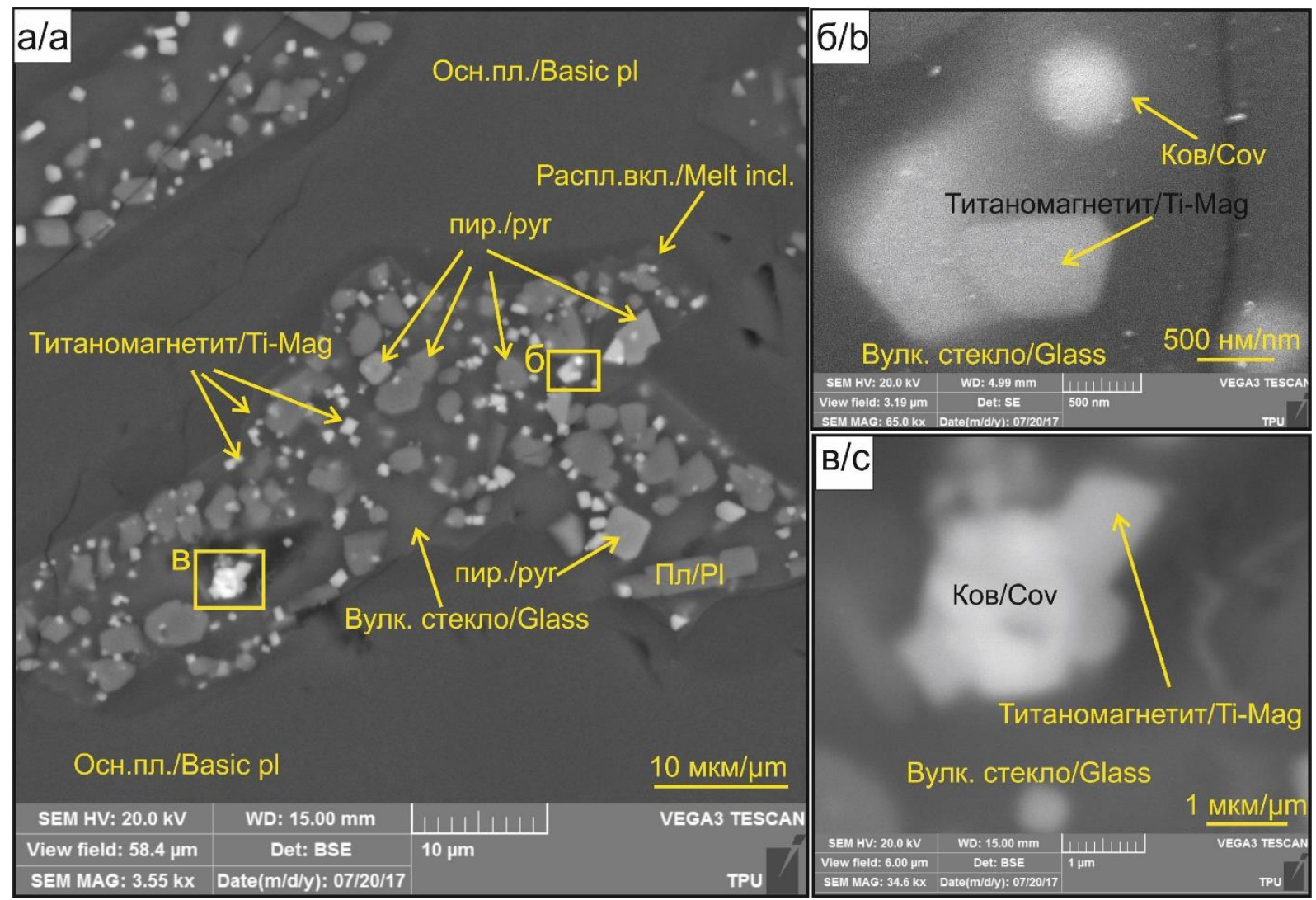

Рис. 4. Вид расплавных включений в порфировых вкрапленниках плагиоклаза (а), содержащих сульфидные глобули (б) и зерна (в), отвечающие по составу ковеллину (Cov). Снимки со сканирующего электронного микроскопа в детекторе обратно-отраженных электронов

Fig. 4. Shape of melt inclusions hosted in plagioclase phenocrysts (a) containing sulfide globules (b) and grains (c), corresponding in composition to covellite (Cov). Images from scanning electron microscope in backscatter electron detector

Рис. 5. Фотографии илифов изучаемых лав вулкана Батур: трахиандезибазальт с вкрапленниками клинопироксена и плагиоклаза в параллельных (а) и скрещенных (б) николях; базальт с зональными вкрапленниками кристаллов плагиоклаза и единичными зернами оливина в параллельных (в) и скрещённых (2) николях; контакт различных по ивету стекол, отражающий смешение различных расплавов (желтая пунктирная линия показывает гранииу между различными по ивету расплавами) с крупными вкрапленниками плагиоклазов с «ячеистой структурой» захвата расплавных включений и кристаллов авгита на фоне микролитовой основной массы в параллельных (д) и скрещенных (е) николях; базальты с вкрапленниками плагиоклаза и оливина в параллельном (ж, и) и отраженном (3, к) свете

Puc. 5. Transmitted-light microphotographs of the studied lavas from the Batur volcano: basaltic trachyandesite with clinopyroxene and plagioclase phenocrysts in plane (a) and cross-polarized (b) light; basalt comprises large prisms of plagioclase with minor amount of olivine grains in plane (c) and cross-polarized (d) light; contact zone of variouscolored melts reflected a possible melts mixing (yellow dotted line separated different color melts) comprises the large plagioclase phenocrysts with a «sieve-textured domains» and augite crystals in the groundmass of plagioclase microlites in plane $(e)$ and cross-polarized $(f)$ light; basalts with plagioclase and olivine phenocrysts in plane $(g, i)$ and cross-polarized $(h, j)$ light. Abbreviations: Pl - plagioclase; Ol - olivine; Cpx - clinopyroxene; Ti-mag titanomagnetite 


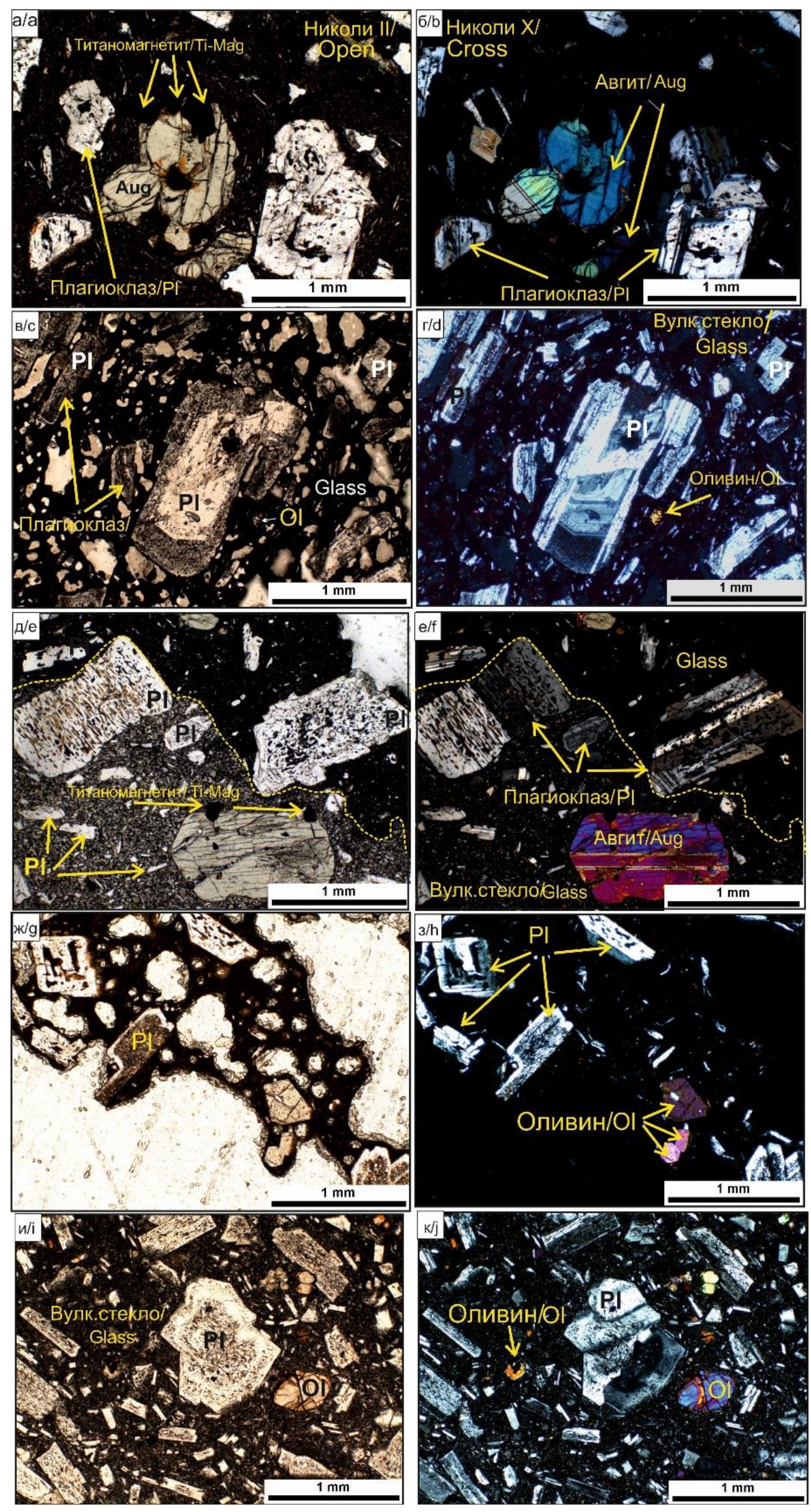


Крупные фенокристы плагиоклазов (размером до 1,5 мм) имеют весьма сложное зональное строение (рис. $5,6,2)$. По составу они соответствует лабрадору - битовниту с содержанием анортитовой молекулы (An $57 . .72 \%$ ). Крупные кристаллы плагиоклазов захватывают по зонам роста вулканическое стекло, титаномагнетит и сульфиды меди, содержание $\mathrm{Cu}$ в отдельных случаях доходит до 75 вес. \%, что соответствует по составу анилиту. В большинстве случаев медный сульфид представлен ковелином. Мелкие кристаллы плагиоклазов спорадически встречаются в стекле основной массы. Их состав более основной по сравнению с крупными вкрапленниками и соответствуют битовниту с содержанием анортитовой молекулы (An 80...85\%). Единичные фенокристы клинопироксена имеют размер зерен $\sim 0,3 \ldots 1,0$ мм и по составу отвечают авгиту. Оливин характеризуется переменным составом с колебанием форстеритовой молекулы Fo $86 . . .46$ \% и образует специфичные структуры с сегрегацией железа по зонам роста кристаллов оливина (рис. 2). Подавляющее большинство зерен оливина имеют именно такой структурный рисунок. Размерность зерен оливина до 0,6 мм, по трещинам и по краям он замещается иддигситом и титаномагнетитом.

Титаномагнетит - главный окисный минерал. Его морфология различна. Он образует как хорошо ограненные идиоморфные кристаллы изометричного и пластинчатого габитуса, так и тонко распыленную мелкую вкрапленность в вулканическом стекле основной массы. Содержание его в породе достигает $5 \ldots 7$ об. \%. В качестве минеральных включений в крупных зернах ( 1 мм) титаномагнетита встречается вулканическое стекло, пироксены (энстатит). Титаномагнетит содержит $\mathrm{Al}_{2} \mathrm{O}_{3}$ и $\mathrm{V}_{2} \mathrm{O}_{5}$ около 1 вес. \%. Помимо титаномагнетита встречается магнетит с примесью $\mathrm{V}_{2} \mathrm{O}_{5}$ до 0,4 вес. \% и $\mathrm{TiO}_{2}$ до 0,3 вес. \% и ильменит.

Трахиандезиобазальт II типа характеризуется наличием вкрапленников плагиоклаза (80...85\%), оливина $(10 \ldots 12 \%)$ и клинопироксена $(5 \ldots 10 \%)$. Количество порфировых вкрапленников от общего объема порфирита составляет не более 40 \%. В образце фиксируются различные по цвету стекла, что, возможно, отражает различную степень окисленности либо результат смешения расплавов (рис. $5, \partial, e)$. При исследовании характера зональности оливина была установлена химическая зональность с накоплением железа в краевых частях (рис. 3). Совместно с железом по краям зерен оливина накапливается и марганец (рис. 3). Размерность зерен оливина варьирует от $0,2 \ldots 1,5$ мм с переменным содержанием форстеритовой молекулы (Fo 68...46 \%) от центра к краям. Клинопироксен по химическому составу отвечает авгиту. Размерность его вкрапленников варьирует в пределах $0,1 \ldots 1,3$ мм. В отдельных фенокристаллах авгита также отмечается прямая химическая зональность с накоплением $\mathrm{Fe}, \mathrm{Mn}, \mathrm{Na}$ и $\mathrm{K}$ в краевых частях. Крупные вкрапленники плагиоклазов (до 2,0 мм) аналогично другим породообразующим минералам имеют сложное зональное строение. По составу фенокристы соответствуют лабрадору-битовниту с содержанием анортитовой молекулы (An 66...80 \%). В них фиксируется как прямая химическая зональность с понижением номера плагиоклаза от центра к краю, так и обратная. В ядерных частях таких зерен содержание анортитовой молекулы колеблется в пределах (An 73...80\%), в то время как в краевых частях (An 66...68\%) соответственно. Также наблюдается обратная зональность, когда в ядерных частях вкрапленников плагиоклаза содержание анортитовой молекулы (An $65 \ldots 68 \%$ ), а в краевой части (An 68...74 \%). Мелкие вкрапленники плагиоклазов, встречающиеся в основной массе вулканического стекла, имеют разнообразный состав - от андезина-лабрадора (An $48 \ldots . .56 \%$ ) до битовнита (c An $~ 80 \%$ ). Плагиоклазы, захваченные в качестве включений в оливине, также по составу отвечают битовниту. Во многих случаях для плагиоклазов характерна своеобразная «ячеистая» структура, которая проявлена в виде ориентированных вдоль удлинения кристаллов расплавных включений, содержащих первичный силикатный и сульфидный расплав (рис. 5, ж, з). В качестве захваченных включений в фенокристаллах плагиоклазов наиболее распространены титаномагнетит и авгит, сульфидные включения представлены преимущественно ковелином (рис. 4).

\section{Петрохимические особенности}

Согласно данным силикатного анализа изученная серия вулканитов представлена базальтами, андезибазальтами и трахиандезибазальтами (таблица, рис. $6, a$ ) c вариацией содержания $\mathrm{SiO}_{2}$ в пределах $49,62 \ldots 54,77$ вес. $\%$.

Для главных петрогенных компонентов отмечается отрицательная корреляция между $\mathrm{TiO}_{2}$ и $\mathrm{MgO}$ и положительная с $\mathrm{Na}_{2} \mathrm{O}$ и $\mathrm{K}_{2} \mathrm{O}$. Для всех образцов характерно повышенное содержание $\mathrm{Al}_{2} \mathrm{O}_{3}(17,2 \ldots 18,8$ вес. \%) и пониженное $\mathrm{MgO}(<4,9$ вес. \%).

Спектры распределения редкоземельных элементов (РЗЭ), нормированные по примитивной мантии (рис. 6, б), образуют отрицательный уровень наклона кривой, что говорит об обогащении легкими редкоземельными элементами (LREE), относительно тяжелых РЗЭ (HREЕ) и имеет типичные признаки островодужного магматизма: выражены тантал-ниобиевый минимумы и высокие концентрации крупноионных несовместимых элементов LILE (Ba, U, Rb, Sr). Европиевый минимум на спектрах отсутствует, что указывает на незначительное фракционирование плагиоклазов в расплаве. Присутствие $\mathrm{Tm}-\mathrm{Yb}$ минимума во всех образцах, вероятно, указывает на фракционирование оливина и пироксена из основной массы.

По данным нашего исследования высокоглиноземистые базальты вулкана Батур сформировали лавовые потоки в период интенсивного вулканизма 1964 г. извержения путем периодического обогащения новых порций высокомагнезиального (оливинового) базальта, поступающего в магматическиую камеру под вулканом. Далее этот расплав поднимался в верхнюю часть камеры с последующим фракционированием оливина и клинопироксена при кристаллизации пла- 
гиоклаза и накоплением его в верхней части магматической камеры. В период поступления новой порции родоначального расплава существующая смесь не успевала прийти в равновесие с поступившей порцией расплава, изливаясь на поверхность и формируя лавовые покровы.

Таблица. Главные компоненты и редкие элементыпримеси в составе лав в. Батур извержения 1964 г.

Table. $\quad$ Major and trace elements composition of rocks from the 1964 Batur volcano eruption

\begin{tabular}{|c|c|c|c|c|c|c|}
\hline $\begin{array}{c}\text { Образец } \\
\text { Sample }\end{array}$ & 1084_1 & 1084_2 & 1084_3 & 1084_4 & 1084_5 & 1084 \\
\hline \multicolumn{7}{|c|}{ Основные компоненты (вес. \%)/Major elements (wt. \%) } \\
\hline $\mathrm{SiO}_{2}$ & 54,77 & 51,39 & 53,46 & 49,62 & 51,31 & 52,24 \\
\hline $\mathrm{TiO}_{2}$ & 1,01 & 0,95 & 1,04 & 0,97 & 0,99 & 0,99 \\
\hline $\mathrm{Al}_{2} \mathrm{O}_{3}$ & 18,58 & 18,29 & 18,79 & 17,20 & 18,00 & 18,03 \\
\hline $\mathrm{Fe}_{2} \mathrm{O}_{3}$ & 6,76 & 8,34 & 3,00 & 4,13 & 1,54 & 5,69 \\
\hline $\mathrm{FeO}$ & 2,34 & 3,12 & 6,54 & 9,85 & 9,81 & 5,45 \\
\hline $\mathrm{MnO}$ & 0,17 & 0,19 & 0,17 & 0,20 & 0,20 & 0,19 \\
\hline $\mathrm{CaO}$ & 6,76 & 7,90 & 7,64 & 7,80 & 8,17 & 7,44 \\
\hline $\mathrm{MgO}$ & 99 & 4,95 & 3,09 & 4,40 & 4,50 & 2,85 \\
\hline $\mathrm{Na}_{2} \mathrm{O}$ & 9 & 2,99 & 3,99 & 38 & 3,40 & 3,60 \\
\hline $\mathrm{K}_{2} \mathrm{O}$ & 1,37 & 0,72 & 1,14 & 0,96 & 0,93 & 1,05 \\
\hline $\mathrm{P}_{2} \mathrm{O}_{5}$ & 0,24 & 0,20 & 0,24 & 0,26 & 0,21 & 0,26 \\
\hline Total & 98,58 & 99,04 & 99,10 & 98,77 & 99,06 & 97,79 \\
\hline \multicolumn{7}{|c|}{ Редкие элементы-примеси (г/т)/Trace elements (ppm) } \\
\hline $\mathrm{Sc}$ & 20,94 & 23,24 & 20,96 & 23,44 & 24,22 & 22,70 \\
\hline $\mathrm{V}$ & 151,38 & 218,90 & 176,81 & 214,75 & 222,35 & 192,41 \\
\hline $\mathrm{Cr}$ & 33,39 & 86,78 & 43,03 & 223,11 & 134,09 & 196,48 \\
\hline Co & 15,81 & 25,43 & 16,30 & 26,81 & 27,53 & 19,54 \\
\hline $\mathrm{Ni}$ & 7,73 & 24,24 & 9,77 & 51,53 & 48,12 & 57,19 \\
\hline $\mathrm{Cu}$ & $\begin{array}{l}75,39 \\
\end{array}$ & 49,33 & 63,94 & 96,56 & 78,71 & 47,85 \\
\hline $\mathrm{Zn}$ & 71,92 & 68,37 & 63,21 & 75,87 & 70,68 & 71,94 \\
\hline $\mathrm{Ga}$ & 12,86 & 10,56 & 10,93 & 11,62 & 11,25 & 12,16 \\
\hline $\mathrm{Rb}$ & 27,95 & 13,79 & 18,93 & 18,68 & 17,51 & 20,16 \\
\hline $\mathrm{Sr}$ & 381,59 & 367,80 & 361,64 & 969,17 & 383,51 & 544,62 \\
\hline $\mathrm{Y}$ & 21,94 & 14,09 & 17,14 & 19,33 & 16,68 & 19,89 \\
\hline $\mathrm{Zr}$ & 91,23 & 53,32 & 67,38 & 66,06 & 63,25 & 75,43 \\
\hline $\mathrm{Nb}$ & 5,67 & 3,14 & 3,74 & 3,58 & 3,42 & 4,26 \\
\hline Mo & & 04 & 42 & 2,96 & 22 & 5,98 \\
\hline Cs & & 34 & 0,56 & 0,56 & 0,53 & 0,62 \\
\hline $\mathrm{Ba}$ & 262,81 & $\begin{array}{l}177,01 \\
\end{array}$ & \begin{tabular}{|l|}
199,85 \\
\end{tabular} & 232,31 & 205,96 & 231,11 \\
\hline $\mathrm{La}$ & 15,03 & 10,08 & 25,08 & 42,41 & 17,38 & 26,07 \\
\hline $\mathrm{Ce}$ & 30,59 & 19,73 & 46,03 & 81,94 & 29,93 & 48,15 \\
\hline $\mathrm{Pr}$ & 3,71 & 2,35 & 5,00 & 8,19 & 3,36 & 5,29 \\
\hline $\mathrm{Nd}$ & 16,05 & 10,04 & 18,87 & 31,86 & 13,53 & 20,34 \\
\hline $\mathrm{Sm}$ & 3,93 & 2,51 & 3,54 & 5,17 & 3,07 & 4,13 \\
\hline $\mathrm{Eu}$ & & 0,93 & 15 & 1,46 & 1,02 & 1,26 \\
\hline $\mathrm{Gd}$ & 99 & 2,64 & 3,43 & 4,40 & 3,18 & 3,97 \\
\hline $\mathrm{Tb}$ & & 42 & 0,54 & 66 & 0,51 & 0,62 \\
\hline Dy & 4,12 & 2,70 & 3,28 & 3,72 & 3,13 & 3,76 \\
\hline Ho & 0,88 & 0,56 & 0,68 & 0,77 & 0,67 & 0,78 \\
\hline $\mathrm{Er}$ & 2,46 & 1,55 & 1,92 & 2,09 & 1,87 & 2,21 \\
\hline $\mathrm{Tm}$ & 0,36 & 0,23 & 0,28 & 0,31 & 0,28 & 0,32 \\
\hline $\mathrm{Yb}$ & 2,32 & 1,48 & 1,82 & 1,96 & 1,75 & 2,06 \\
\hline $\mathrm{Lu}$ & 0,35 & 0,23 & 0,28 & 0,30 & 0,27 & 0,31 \\
\hline $\mathrm{Hf}$ & 2,49 & 1,48 & 1,85 & 1,81 & 1,74 & 2,08 \\
\hline $\mathrm{Ta}$ & 39 & 0,21 & 0,26 & 0,24 & 0,23 & 0,28 \\
\hline $\mathrm{Pb}$ & 5,10 & 6,06 & 14,51 & $\begin{array}{ll}11,61 \\
\end{array}$ & 4,08 & 7,04 \\
\hline Th & 2,81 & 1,61 & 2,70 & 3,59 & 1,86 & 2,86 \\
\hline $\mathrm{U}$ & 0,68 & 0,41 & 1,05 & 1,07 & 0,47 & 0,78 \\
\hline
\end{tabular}

Примечание: 1084_1 - Трахиандезибазальт/Basaltic trachyandesite; 1084_2 - Базальm/Basalt; 1084_3 - Tpaхиандезибазальт/Basaltic trachyandesite; 1084_4 - Базальт/Basalt; 1084 5-Базальт/Basalt; 1084_6-Андезибазальт/Basalticandesite.

\section{Выводы}

1. Все образцы изученных вулканитов имеют порфировую структуру и содержат вкрапленники плагиоклаза $(17 . .23$ об. \%), оливина (3 об. \%) и пироксена (2 об. \%), расположенные в мелкозернистой массе мезостазиса, содержащего плагиоклаз, титаномагнетит, пироксен и вулканическое стекло. Для порфировых вкрапленников плагиоклаза характерна «ячеистая» структура, которая проявлена в виде ориентированных расплавных включений ( 0,05 мм), содержащих первичный силикатный и сульфидный расплавы. В большинстве случаев плагиоклазы соответствуют по составу лабрадорбитовниту, что согласуется с принадлежностью пород к базальтовой и базальто-андезитовой серии.

2. Изучение андезибазальтов палеокальдеры действующего вулкана Батур свидетельствует об активном участии в образовании исследуемых пород сложных процессов дифференциации, ассимиляции и смешения, оказывающих непосредственное влияние на состав породообразующих минералов и конечный состав пород. По петрохимическим показателям породы относятся к высокоглиноземистым базальтам $\left(\mathrm{Al}_{2} \mathrm{O}_{3} \geq 18,0\right)$, характерным для современного островодужного магматизма, главным минералом-концентраторам алюминия в которых выступает плагиоклаз.

3. Сложный характер зональности порфировых вкрапленников плагиоклазов согласуется с быстрым охлаждением исходных расплавов, когда выделяющийся плагиоклаз не успевает прийти в равновесие с оставшейся еще жидкой магмой. Другим объяснением сложного строения плагиоклазовых вкрапленников с округлыми внутренними зонами могут являться процессы дегазацией магмы при извержении, что связано со вскипанием и повышением температур, приводящих к оплавлению границ кристаллов, которые впоследствии обрастают внешними каймами.

4. В изучаемых лавах наблюдается несколько вариантов перераспределения железа в оливине: накопление его в краевой части зерен, специфичные «структуры распада» с фазой «окси-оливина» и незональные кристаллы оливина с магнезиальностью 66. Повышенная железистость оливина и примесь в нем $\mathrm{MnO}$ (до 2,23 вес. \%) подтверждают тот факт, что породы являются производными базальтовых расплавов с щелочным уклоном

5. Включения глобулей ковеллина и халькопирита в расплавных включениях свидетельствуют о наличии высокофракционированного высокомедистого по составу расплава на более глубинном уровне.

Работа выполнена в рамках программы повышения конкурентоспособности ТПУ.

Выражаем благодарность Гаврилову Роману Юрьевичу за помощь в проведении аналитических исследований по определению основных оксидов с помощью силикатного анализа и редких элементов методом масс-спектрометрии $c$ индуктивно-связанной плазмой. Выражаем признательность Краснощековой Любовь Афанасьевне за помощь в проведении фотосьемки прозрачных шллфов, а также благодарим Мазурова Алексея Карповича за написание речензии. 

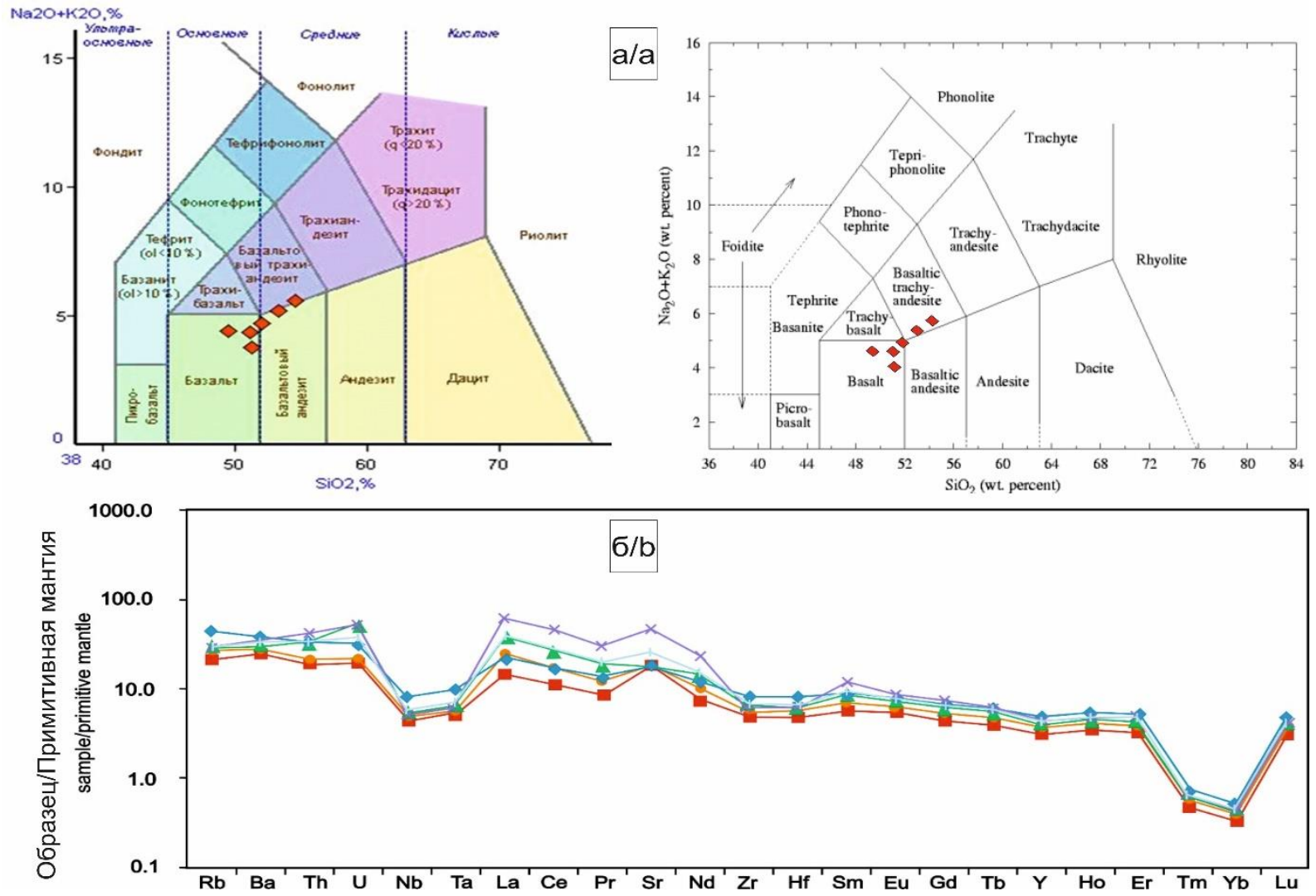

Pис. 6. Составы изучаемых пород на диаграмме общей кислотности-щелочности пород [30] (а); нормализованные на примитивную мантию по [31] литофильные редкие элементы изучаемых лав 1964 г. извержения вулкана Батур (б)

Fig. 6. Total alkali-silica diagram showing the location of the studied lavas from the Batur volcano [30] (a); primitive mantle-normalized after [31] lithophile trace element compositions of lavas from the 1964 Batur eruption (b)

\section{СПИСОК ЛИТЕРАТУРЫ/REFERENSES}

1. Ben-Avraham Z., Emery K. O. Structural framework of the Sunda Shelf. Bulletin of American Association of Petroleum Geologists, 1973, vol. 57, pp. $2823-2366$

2. Whitford D.J. Strontium isotopic studies of the volcanic rocks of the Sunda arc, Indonesia, and their petrogenesis. Geochimica et Cosmochimica Acta, 1975, vol. 39, pp. 1287-1302.

3. Curray J.R., Shor G.G., Raitt R.W., Henry M. Seismic refraction and reflection studies of crustal structure of the eastern Sunda and western Banda arcs. Journal of Geophysical Research, 1977, vol. 82, pp. 2479-2489.

4. Hamilton W.B. Tectonics of the Indonesian Region. Washington, US Geological Survey Professional Papers 1078, 1979. 345 p.

5. Kent A.J.R., Darr C., Koleszar A.M., Salisbury M.J., Cooper K.M Preferential eruption of andesitic magmas through recharge filtering. Nature Geoscience, 2010, vol. 3, pp. 631-636.

6. Dungan M.A., Wulfe A., Thompson R. Eruptive stratigraphy of the Tatara-San Pedro complex, $36^{\circ} \mathrm{C}$, Southern Volcanic Zone, Chilean Andes: reconstruction method and implications for magma evolution at long-lived arc volcanic centers. Journal of Petrology, 2001, vol. 42, pp. 555-626.

7. Yakich T., Brzozowski M., Chernishov A., Grieco G., Savinova O., Timkin T., Marfin A. Petrological Features of the Burlakski and Nizhne-Derbinsk Mafic-Ultramafic Plutons (East Sayan Mountains, Siberia, Russia). Minerals, 2020, vol. 10 (119), pp. $1-$ 22.

8. Ruprecht P., Plank T. Feeding andesitic eruptions with a high-speed connection from the mantle. Nature, 2013, vol. 500, pp. 68-72.

9. Oeser M., Ruprecht P., Weyer S. Combined Fe-Mg chemical and isotopic zoning in olivine constraining magma mixing-to-eruption timescales for the continental arc volcano Irazú (Costa Rica) and
Cr diffusion in olivine. American Mineralogist, 2018, vol. 103, Iss. 4, pp. 95-105.

10. Shea T., Costa F., Krimer D., Hammer J.E. Accuracy of timescales retrieved from diffusion modeling in olivine: A $3 \mathrm{D}$ perspective. American Mineralogist, 2015, vol. 100, pp. 2026-2042.

11. Portnyagin M., Mironov N., Botcharnikov R., Gurenko A., Almeev R.R., Luft C., Holtz F. Dehydration of melt inclusions in olivine and implications for the origin of silica-undersaturated island-arc melts. Earth and Planetary Science Letters, 2019, vol. 517 , pp. $95-105$.

12. Arif J., Baker T. Gold paragenesis and chemistry at Batu Hijau, Indoneisa: implications for gold-rich porphyry copper deposits. Mineralium Deposita, 2004, vol. 39, Iss. 5-6, pp. 523-535.

13. Cooke D.R., Hollings P., Walshe J.L. Giant porphyry deposits: characteristics, distribution, and tectonic controls. Economic Geology, 2005, vol. 100, Iss. 5, pp. 801-818.

14. Richards J.P. Giant ore deposits formed by optimal alignments and combinations of geological processes. Nature Geoscience, 2013, vol. 6, Iss. 13, pp. 911-916.

15. Yuningsih E.T., Matsueda, H.R., Mega F. Epithermal gold-silver deposits in western Java, Indonesia: Gold-silver Selenide-Telluride mineralization. Indonesian Journal on Geoscience, 2014, vol. 1, Iss. 2, pp. 71-81.

16. Ziaii M., Safari S., Timkin T., Voroshilov V., Yakich T. Identification of geochemical anomalies of the porphyry-Cu deposits using concentration gradient modelling: a case study, Jebal-Barez area, Iran. Journal of Geochemical Exploration, 2019, vol. 199, pp. 16-30.

17. Kamenetsky V.S., Kamenetsky M.B. Magmatic fluids immiscible with silicate melts: examples from inclusions in phenocrysts and glasses, and implications for magma evolution and metal transport. Geofluids, 2010, vol. 10, pp. 293-311. 
18. Zelenski M., Kamenetsky V.S., Mavrogenes J.A., Gurenko A.A., Danyushevsky L.V. Silicate-sulfide liquid immiscibility in modern arc basalt (Tolbachik volcano, Kamchatka). P. I. Occurrence and compositions of sulfide melts. Chemical Geology, 2017, vol. 478, pp. $102-111$.

19. Kamenetsky V.S., Zelenski M., Gurenkoc A., Portnyagin M., Ehrig K. Kamenetskya M., Churikova T., Feig S. Reprint of silicate-sulfide liquid immiscibility in modern arc basalt (Tolbachik volcano, Kamchatka). P. II. Composition, liquids assemblage and fractionation of the silicate melt. Chemical Geology, 2017, vol. 472, pp. 313-345.

20. Zelenski M., Kamenetsky V.S., Mavrogenes J.A., Danyushevsky L.V., Matveev D., Gurenko A.A. Platinum-group elements and gold in sulfide melts from modern arc basalt (Tolbachik volcano, Kamchatka). Lithos, 2017, vol. 290, pp. 172 188.

21. Plank T., Langmuir C.H. The chemical composition of subducting sediment and its consequences for the crust and mantle. Chemical Geology, 1998, vol. 145, pp. 325-394.

22. Widiyantoro S., Van der Hilst R. Structure and evolution of lithospheric slab beneath the Sunda Arc, Indonesia. Science, 1996, vol. 271, pp. 1566-1570.

23. De Mets C., Gordon R.G., Argus D.F., Stein S. Current plate motions. Geophysical Journal International, 1990, vol. 101, pp. $425-478$.

24. Tregoning P., Brunner F.K., Bock Y., Puntodewo S.S.O., McCaffrey R., Genrich J.F., Calais E., Rais J., Subarya C. First geodetic measurement of convergence across the Java Trench. Geophysical Research Letters, 1994, vol. 21, pp. 2135-2138.

25. Simandjuntak T.O., Barber A.J. Contrasting tectonic styles in the Neogene orogenic belts of Indonesia. Tectonic Evolution of Southeast Asia. Geological Society Special Publication, 1996, vol. 106, pp. 185-201.

26. Katili J.A. Volcanism and plate tectonics in the Indonesian island arcs. Tectonophysics, 1975, vol. 26, pp. 165-188

27. Carlile J.C., Mitchell A.H.G. Magmatic arcs and associated gold and copper mineralization in Indonesia. Journal of Geochemical Exploration, 1994, vol. 50, pp. 91-142.

28. Metchalfe I. Pre-Cretaceous evolution of SE Asian terranes. Tectonic Evolution of Southeast Asia. Geological Society Special Publication, 1996, vol. 106, pp. 97-122.

29. Wheller G.E., Varne R. Genesis of dacitic magmatism at Batur volcano, Bali, Indonesia: implications for the origin of stratovolacano calderas. Journal of Volcanology and Geothermal Research, 1986, vol. 28, pp. 363-378.

30. Le Bas M.J., Le Maotre R.W., Streckeisen A., Zanettin B. A chemical classification of volcanic rocks based on the total alkalisilica diagram. Journal of Petrology, 1986, vol. 27, pp. 745750.

31. Sun S.S., McDonough W.F. Chemical and isotopic systematics of oceanic basalts: implications for mantle composition and processes. Magmatism in the Oceanic Basins: Geol. Soc. Spec. Publ., 1989, vol. 42, pp. 313-345.

Поступила/Received: 03.06.2020.

\section{Информация об авторах}

Якич Т.Ю., кандидат геолого-минералогических наук, доцент отделения геологии Инженерной школы природных ресурсов Национального исследовательского Томского политехнического университета.

Савинова O.B., кандидат геолого-минералогических наук, доцент отделения геологии Инженерной школы природных ресурсов Национального исследовательского Томского политехнического университета.

Рудмин М.A., кандидат геолого-минералогических наук, доцент отделения геологии Инженерной школы природных ресурсов Национального исследовательского Томского политехнического университета. 
UDC552.113

\title{
PETROLOGICAL FEATURES OF MODERN ARC VOLCANISM ON THE EXAMPLE OF BATUR VOLCANO LAVAS (BALI ISLAND, INDONESIA)
}

\author{
Tamara Yu. Yakich', \\ cherkasovatu@tpu.ru
}

\section{Olesya V. Savinova 1 ,} logvinenkoov@tpu.ru

\author{
Maxim A. Rudmin'1, \\ rudminma@tpu.ru \\ 1 National Research Tomsk Polytechnic University, \\ 30, Lenin avenue, Tomsk, 634050, Russia.
}

The relevance of the modern volcanism study is to understand the complex processes of the magma differentiation, assimilation and
mixing that recorded in the mineralogical, structural and petrochemical features of volcanic rock units. On the other hand, economically
significant deposit of non-ferrous and noble metals is often associated with basic volcanism of increased alkalinity in modern island-arc
systems.
The main aim of this work is to study and interpret the mineralogical and petrochemical features of the lavas from the active Batur volcano (Bali Island, Indonesia).

Objects: samples of lava from the 1964 Batur eruption.

Methods. The rock units of modern island arc lavas and the minerals found in them have been studied by optical and electron microscopy using energy dispersive spectroscopy analysis. The major elements of the rock units were obtained using silicate analysis, while trace element composition - using inductively coupled plasma mass spectrometry analysis. As a result of the conducted studies it was found that all samples of the lavas from Batur volcano have porphyry structure and contain phenocrysts of plagioclase (17...23 vol. \%), olivine (3 vol. \%) and pyroxene (2 vol. \%) located in the fine-grained ground mass containing plagioclase, titanomagnetite, pyroxene and volcanic glass. The phenocrysts of plagioclase are characterized by a "sieve-textured domains» structure, with oriented melt inclusions $(\sim 0,05 \mathrm{~mm})$ containing primary silicate and sulfide melts. The petrochemical parameters of the Batur lavas suggest that they correspond to highalumina basalts $\left(\mathrm{Al}_{2} \mathrm{O}_{3} \geq 18,0\right)$. The complex structure of zonal plagioclase phenocrysts is consistent with the rapid cooling of the initial melts, when the released plagioclase cannot come into equilibrium with the remaining liquid magma. Its bulk chemical composition corresponds to labrador-bytownite. Olivine reveals several variants for iron redistribution in its composition including zonal crystals with iron accumulation in the marginal parts of grains, specific "excolutions structures» and homogeneous olivine crystals with $M g \#(F o)$ $\left[=\mathrm{Mg} /\left(\mathrm{Fe}^{2+}+\mathrm{Mg}\right)^{*} 100 \%\right.$ atomic ratio] component $\sim 66,0$. The increased iron content and manganese oxide alloy $\left(\mathrm{Mn}^{2+}\right)$ in olivine may indicate that the Batur lavas are derivatives from the olivine basalt with an alkaline bias. Presumably, during the period of intense volcanism Batur volcano eruption in 1964, the magma chamber was periodically enriched with olivine basalt at some regularity. Further, this melt rose to the upper part of the chamber, followed by fractionation of olivine and clinopyroxene during crystallization of plagioclase and their accumulation in the upper part of the magma chamber. During the period of the input of a new portion of the initial melt, the existing mixture had not come into equilibrium with the incoming portion of the melt, has erupted to the surface and formed the lavas of high-alumina basalt. The presence of covellite and chalcopyrite globules in melt inclusions in the phenocrysts of plagioclase may be the evidence of the existence of a highly fractionated sulfide melt at a deeper level.

\section{Key words:}

Modern island-arc volcanism, high-alumina basalts, plagioclase, olivine, melt inclusions, sulfide globules.

The research was carried out within the frame of the TPU Competitiveness Enhancement Program.

The authors express thanks to Roman Yu. Gavrilov for assistance in analytical studies in determining the main oxides by silicate analysis and rare elements by the method of mass-spectrometry with inductively coupled plasma, to Lyubov A. Krasnoshchekova for aid in taking of pictures of thin sections, to Aleksey K. Mazurov for review.

\section{Information about the authors}

Tamara Yu. Yakich, Cand. Sc., associate professor, National Research Tomsk Polytechnic University. Olesya V. Savinova, Cand. Sc., associate professor, National Research Tomsk Polytechnic University. Maxim A. Rudmin, Cand. Sc., associate professor, National Research Tomsk Polytechnic University. 